REPRODUCTION

\title{
A wrongful existence in the Netherlands
}

\author{
H F L Nys, J C J Dute
}

J Med Ethics 2004;30:393-394. doi: 10.1136/jme.2003.005215

W rongful life claims have always been controversial. Courts in England, ${ }^{1}$ the USA, ${ }^{2}$ and Australia ${ }^{3}$ have generally refused to accept them. However, are wrongful life claims becoming more commonly accepted in continental Europe? After the widely discussed Perruche case in France (now overruled by article 1 of the Act of 4 March 2002 stating that no one can sue for damages for the sole fact of their birth), ${ }^{4}$ and a judgment of a Brussels tribunal in July 2002 that has passed almost unnoticed, the Court of Appeal of The Hague, the Netherlands, in a lengthy and motivated judgment of 26 March 2003, awarded moral damages to a child born with a severe chromosomal disease. ${ }^{5}$ This judgment differs from the Perruche and Brussels judgments in that both of the latter failed to show to what extent the negligence towards the mother can at the same time be a negligence towards the unborn child. The Court of Appeal of The Hague did at least attempt to explain this.

According to the Court of Appeal the midwife looking after the mother had a legal obligation not only towards the pregnant woman but also towards her fetus. This obligation can be derived from the medical treatment contract concluded between, on one hand, the employer of the midwife, the Leiden University Medical Centre, and on the other hand, the parents of the child. The Court held that the unborn child could legally be considered as a party to this contract. But even when one does not accept the existence of a contract between the hospital and the child, the Court noticed that it does not alter the fact that the hospital is under legal obligation to take care of the interests of the unborn child. The medical treatment contract between the hospital and the mother in any case implies an obligation to take care of the interests of the unborn child.

The parents of the child had informed the midwife that a nephew of the father was disabled because of a chromosomal abnormality. Notwithstanding this information, no family history had been taken nor had a centre for clinical genetics been consulted. The abnormality was therefore not detected early enough and the baby was born with multiple mental and physical disabilities: she cannot walk, talk, or properly recognise her parents; she has deformed feet and is believed to be in constant pain; she has undergone several heart operations; and at the age of two and a half years she had been admitted to hospital nine times due to "inconsolable crying". By withholding from the mother crucial information about the health status of her child, the midwife acted wrongfully towards the mother. This negligence consisted in infringing her legal right to opt for an abortion. The hospital argued that it had not been demonstrated that the mother would have opted for an abortion if she had been correctly informed about the health status of her child. According to the Court, however, one could reasonably assume that given the circumstances of the case, an abortion would have been performed if the mother had been correctly informed. Damages against the hospital amounting to the costs of the child's care and upbringing until her twenty first birthday were awarded to the parents (this is what is commonly known as a wrongful birth claim).
The Court went further, ruling that the child herself is also entitled to compensation in respect of non-pecuniary damages. To obtain this result the Court reasoned as follows. First, as noted before, it accepted that the hospital and the midwife had a legal obligation to take care of the interests of the unborn child. The unborn child may derive rights of its own from this obligation. Secondly, the Court accepted a causal relationship between the fault of the midwife and the chromosomal disease the child is suffering from. Although from a medical-biological point of view this disease exists independently of the behaviour of the midwife, its possible presence could have been detected by genetic testing, which was not done because of negligence. Timely human intervention could have prevented the birth of the handicapped child. From the legal point of view, it is this professional mistake that caused the damage the child is suffering from, since the damage was an entirely foreseeable consequence of the professional mistake that for that reason should not have been made. The Court continued by stating that it is not determining life or death of the child. It is up to the parents and only to them to take such decisions with regard to the legal requirements. One has to respect the decision of the parents to terminate the pregnancy bearing in mind the serious risks threatening their child which indeed manifested themselves afterwards. For these reasons the Court accepted a wrongful life claim in principle.

We appreciate that the Court of Appeal of The Hague has made an effort to elaborate on the negligent character of the behaviour of the midwife towards the child. In other wrongful life judgments this important issue has been neglected. However, we are not sure whether the reasoning is convincing in all respects. Of course the midwife had a legal obligation to take care of the interests of the unborn child. Not respecting these interests by causing injury to her, be it by act or by omission, amounts to liability. When the Court uses the expression "this professional mistake" it is not entirely clear what this refers to. In grammatical terms, there are two possibilities: (a) not performing the genetic test that was indicated in this particular case or $(b)$ not giving the opportunity to the parents (the mother) to prevent the birth of a handicapped child. In the latter case it is difficult to see how the improper counselling of the parents (the mother) can at the same time be negligent behaviour towards the unborn child. What could the child have done with such information? Ask that its birth could have been prevented by timely human intervention? If this is the negligence towards the child, in what respect does it differ from the negligence towards the mother? Also, we wonder whether there is an interest in that one's birth "is prevented by timely human intervention". In other words, is there a legally protected interest in not being born? Is there a "right not to be born"? ${ }^{67}$

Does the failure to recognise a wrongful life claim creates a duty free zone within which doctors owe no duty to act carefully or reasonably with respect to the advice they provide? We don't think so, because the mother can always institute proceedings for damages. It is true, however, that a 
wrongful life claim enables the child to receive payment for pecuniary damages suffered after her twenty first birthday.

The Court of Appeal of The Hague really struggled with these questions. It expressly refers to the controversies that surround wrongful life claims inside and outside Europe. It also expressly refuses to consider a handicapped child as damage. But it upholds its conclusion as to the acceptability of a wrongful life claim in the law prevailing in the Netherlands as inescapable. It is up to the legislator to ban or limit such claims, the Court held. In this respect it is interesting to note that Boris Dittrich (Member of Parliament for the left wing liberal party D-66) has called for Dutch law to be changed to prohibit wrongful life claims. The Dutch Minister of Justice Donner has stated that the subject matter indeed has to be decided by the legislator, but in what way is not clear yet (in the Netherlands the legislative function is carried out by government and parliament working jointly together). ${ }^{8}$ It should be noted that the Court's decision is not final yet. An appeal on points of law has been lodged with the Supreme Court.

\section{Authors' affiliations}

H F L Nys, Centre for Biomedical Ethics and Law, University of Leuven, and Department of Health Law, Maastricht University, the Netherlands
J C J Dute, Department of Health Law, Maastricht University, the Netherlands

Correspondence to: H F L Nys, Department of Health Law, Maastricht University, PO Box 616, 6200 MD, Maastricht, the Netherlands; h.nys@ zw.unimaas.nl

Received 11 June 2003

Revised version received 3 September 2003

Accepted for publication 5 February 2004

\section{REFERENCES}

1 McKay $v$ Essex Health Authority [1982] 2 All ER 771 (CA)

2 Edwards $v$ Blomeley [2002] NSWSC 460; Harriton $v$ Stephens [2002] NSWSC 461; Waller $v$ James [2002] NSWSC 462, (see www.austlii.edu.au/ au/cases/nsw/supreme ct).

3 For instance: Kassama $v$ Magat, Court of Special Appeals of Maryland, February 2001

4 See about this in: Duguet AM. Wrongful life: the recent French Cour de Cassation decisions. Eur J Health Law 2002;9:139-49.

5 Sheldon T. Court awards damages to disabled child for having been born. BMJI 2003;326:784.

6 Spriggs M, Savulescu J. The Perruche judgment and the "right not to be born". J Med Ethics 2002;28:63-4.

7 Savulescu J. Is there a "right not to be born"? Reproductive decision making and the right to information. J Med Ethics 2002;28:65-7.

8 TK 2002/2003 Aanhangsel van de Handelingen (Appendix to the official report of the Lower House) nr 1205.

\section{$\mathrm{ECHO}$}

\section{Quality improvement projects and research review}

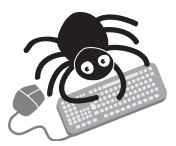

Please visit the Journal of Medical Ethics website [www. jmedethics. com] for a link to the full text of this article. eeking to improve service by audit or quality improvement projects is a continuous $\mathrm{S}$ obligation for health care professionals. Putting obstacles in the way of such activities might lead to perpetuation of poor practices. Some quality improvement projects, however, may be fairly complex and the changes made may entail a possibility of harm to some patients. Such projects may be regarded as research and for the protection of patients they may be required to submit to formal review by research review boards and ethics committees. Such a requirement would, however, inhibit many improvement projects and overburden hospital ethical committees. So when does an improvement project become research and how do we distinguish between the two?

In 2000, workers in Pittsburgh, Pennsylvania published a paper describing a quality improvement project involving all renal dialysis centres in the state. In some centres dialysis was often performed for shorter times than prescribed and physicians had therefore prescribed longer times than needed in order to achieve the times they wanted. By regular review and by comparing poorer performing centres with better performing centres improvements were achieved over several months. When the paper was reported to the local Institutional Review Board it ruled that the project was research and should have been submitted for review. Two other professional bodies gave conflicting opinions as to whether the project was or was not research. As a result quality improvement projects in End Stage Renal Disease networks have been impeded.

Various features that make projects research have been put forward, such as anticipated generalisability of results, lack of direct benefit to patients, use of new procedures, or use of a control group. The author of this paper adds to the list substantial funding, nontherapeutic aims, and individual patients rather than care systems or providers as subjects. Quality improvement, as opposed to research, provides rapid feedback to the care system generating the data with the aim of changing practice within that system.

In view of the lack of consensus on the issue a series of meetings and papers is to be led by the Hastings Centre in New York. (To sign on for a working online conference go to www.medicaring.org and to "online conference". Information from info@medicaring.org) A Quality and Safety in Health Care 2004;13:67-70. 